\title{
Can Tax Policy Contribute to the Crisis?
}

\author{
Irena Szarowská
}

\begin{abstract}
The discussion about causes of financial and economic crisis has focused also on tax consequences and measures. Taxes have not generated the crisis, but some aspects of tax policy may have led to increased risk-taking and indebtedness of banks, households and companies. The aim of the paper is to review main channels through which the tax policy can affect financial markets and financial stability. Attention is focused on taxation of financial institutions, tax reliefs for housing and for capital gains, tax preference for corporate debt financing. The paper examines last development and also current regulation and tax measures realized by national policymakers and European Commission with the goal to avoid future crises. The paper employs standard methods of scientific paper; mainly the method of description and comparative analysis.
\end{abstract}

Index Terms-Crisis, corporate debt financing, reliefs for housing, taxation of financial institutions.

\section{INTRODUCTION}

There is a general consensus that the 2008 financial crisis is the worst economic crisis since the Great Depression of 1929. As [1] mention, it has been characterized by a housing bubble in a context of rapid credit expansion, high risk-taking and exacerbated financial leverage, leading to deleveraging and credit crunch when the bubble burst. Economists and researchers have tried to identify causes which have caused or co-caused the crisis. This effort has a very simple and logical reason - identifying and understanding problems can help to prevent future crises. As [2] emphasizes, root causes of the financial crisis can be identified at two levels: global liquidity policies (especially low interest rates in particular nurturing a strong credit expansion with cheap leverage and bubble tendencies in asset prices); plus a poor regulatory framework, which not only failed to prevent the growth of asset bubbles but actually contributed to their growth and concentration into the specific areas, such as mortgage securitization, where the credit bubble eventually burst with such damaging consequences. More immediate causes of the crisis can be categorized as follows:

- A high appetite for yield and a high tolerance of risk;

- Lack of transparency;

- Insufficient regulation;

- Lack of adequate corporate and fiscal governance.

The discussion has focused also on the tax policy and measures. The complexities of national tax codes, and the international interaction between them encouraged the use of

Manuscript received April 25, 2013; revised June 30, 2013. This paper ensued thanks to the support of the grant GAČR 403/11/2073 "Procyclicality of financial markets, asset price bubbles and macroprudential regulation".

I. Szarowská is with the Silesian University, School of Business Administration, Univerzitni nam. 1934, 73340 Karvina, Czech Republic (e-mail: szarowska@opf.slu.cz). complicated financial instruments and international tax planning, reducing transparency. [3]-[6] and others have tried to answer the question whether taxation and tax policy can play any role in precipitating the financial crisis. They have considered as the most important elements of the tax system affecting financial crisis: the tax preference for corporate debt financing, the taxation of financial institutions, tax competition, tax reliefs for housing and for capital gains, the incoherence of capital income taxation (tax arbitrage, tax clienteles, and derivative securities), the use of tax havens for creating tax efficient securitization instruments and the tax preference of the performance-based remuneration.

The aim of the paper is to review main channels through which the tax policy can contribute to the crisis. Attention of the paper is focused (due to the length of the article) only on tax reliefs for housing and capital gains, tax benefits for corporate debt financing and taxation of financial institutions. The paper examines development and also possible tax measures and regulation.

The paper employs standard methods of scientific paper. Mainly the methods of description and comparative analysis are applied.

\section{TAX RELIEFS FOR HOUSING}

The paper starts with the tax treatment of housing as housing, and in particular the collapse of the housing price bubble, has been singled out as a triggering cause of the crisis. Tax policy can affect two key aspects of housing markets: house prices and households' leverage. These are interrelated, as high house prices encourage removing equity through increased borrowing, the availability of cheap loans drives up house prices, and the expectation of price increases raises the expected return on borrowing to acquire housing. There is a considerable diversity of housing tax regimes across countries. Definite international comparison is difficult due to the complexity of tax codes and differences in terms of deductions, exceptions or threshold limits.

Study of [7] points out the risks in distorting a market so central to financial stability reinforce long-standing efficiency and equity arguments for more neutral taxation. Taxation of capital gains is needed to match the capital gains tax liability on other financial assets; and deductibility of mortgage interest is needed to match the taxation of the interest available from investing in other assets. From a theoretical point of view, the non-taxation of the rental return to owner-occupied housing, coupled with the deductibility of mortgage interest and home equity loan interest for itemizers and especially favorable statement of capital gains on housing, adds up to a substantial tax preference. Unfortunately, tax systems are not neutral. Owner-occupation is tax-favored with respect to renting in 
many countries, and with respect to most forms of return on personal savings.

In practice, imputed rents and capital gains on primary residences are rarely taxed, creating a general bias towards housing that mortgage interest relief is likely to reinforce. Very few countries bring imputed rents into the income tax (the Netherlands, Belgium and Switzerland being exceptions). Some tax capital gains on owner-occupied housing, but typically more lightly than other income or only beyond a high threshold (or both). Even in the absence of distortions on the financing side, these features would tax-favor owner-occupation relative to renting. And mortgage interest costs attract tax relief, subject to limits, in a number of countries (e.g. Denmark, France, Italy, Spain, Italy, France, U.S., UK, Ireland, Netherlands, and Czech Republic). Since borrowing to acquire other assets is generally not deductible, this makes investment in housing even more favored. Look at [6] or Taxes in Europe database for details.

Mortgage interest relief would not tax-favor mortgage finance if the alternative to borrowing were investing less in fully-taxed assets and other interest were also deductible. If alternative investments were fully taxed, mortgage interest deductibility would mean that the opportunity costs of acquiring housing by borrowing and by running down other assets would in each case be the after-tax interest rate-so mortgage finance would not be tax -favored. Many countries, however, tax other forms of saving (such as pensions) at reduced rates. In that case, if the return on those assets matches the pre-tax interest rate on mortgage debt, there is an arbitrage gain from leveraging against housing and investing own-funds in the non-housing asset. And while interest on loans used to finance consumption is generally not deductible, home equity loans have provided (within limits) just such a tax-favored way to borrow and spend.

The distributional impact of mortgage interest relief can be complex, but deductibility likely favors the better off. Higher income individuals may be more likely to face constraints on their access to tax-favored assets (since this is often subject to caps), so that their opportunity cost of investing in housing is the after-tax return. This creates an argument for some tax relief to ensure that the less well-off also pay an after-tax rate. Against this, however, deductions are worth more to the better-off as they take them against a higher marginal rate of tax. The second effect would be avoided if relief were provided - as many countries do — not as a deduction but as a credit.

As [8] and next [9] have stated, the deductibility of mortgage interest, by reducing the user cost of ownership, decreases the price elasticity of demand; it therefore increases the volatility of the housing market. In general, the price sensitivity of demand for housing is inversely related to the extent of preferential tax treatment for housing and to the expected rate of house price appreciation. Moreover, [4] note that mortgage interest tax relief encourages the build-up of gross housing debt and there is evidence that countries offering more favorable tax treatment for home ownership do indeed have higher ratios of mortgage debt. There is also evidence that mortgages fell significantly relative to home value (in UK and U.S.) after reforms reduced the value of mortgage interest relief (e.g. in Scandinavian countries).

Ownership or occupation and transaction taxes also play an important role. Many countries charge substantial recurrent taxes based on ownership or occupation. These have potential appeal both in serving as user charges reflecting the value of local public services and, to the extent that these and other features are location-specific, as being less vulnerable to interjurisdictional tax competition than the corporate income tax and other taxes on more mobile bases.

For instance, [10] have presented evidence that such taxes (along with consumption taxes) have significantly less adverse effects on growth than income taxation. Also [11] have highlighted that economic activity somehow related to housing accounts for an important share of GDP. In Europe, this share is estimated at between 5 and 10 per cent. Next, [12] have identified five main channels through which the housing market affects public finances: property tax revenues, transfer tax revenues, sales tax revenues, and personal income tax revenues. They found that property tax revenues do not tend to decrease following house price declines and concluded that the resilience of property tax receipts is due to significant lags between market values and assessed values of housing and the tendency of policy makers to offset declines in the tax base with higher tax rates. The other four channels have had a relatively modest effect on state tax revenues and public finances. It is necessary to have on mind that a shortfall in public revenue may cause a debt problem.

Furthermore, investors paying tax on interest income at a rate higher than that at which they can offset capital losses benefit by pooling assets to pay interest at a rate which reflects the expected losses. Investors facing the same rate on both, on the other hand, do not care about the mix of interest and gains. Bringing the two types together creates scope for tax arbitrage from which both can benefit, as [13] summarizes in his argument.

The search for new ways to allocate risk has encouraged to the development of new financial instruments, in particular the technique of securitization. The most common securitizations (in relations to the housing) are mortgage-based securities (MBSs) whereby the claims of thousands of mortgages are pooled together in a Special Purpose Vehicle (SPV), which is a legal entity outside of the balance-sheet of the financial institution, allowing them to bypass capital ratios regulations. Tax issues raised by securitization include: whether any gains on assets placed in the SPV by the originator are taxable; whether the SPV itself is taxable; and whether payments to holders of the securitized assets will be taxed as interest or dividends. MBSs can be divided between commercial MBSs (CMBSs), secured by commercial and multifamily properties, and residential MBSs (RMBSs).

But [7] highlights that a lack of clarity in the tax treatment of new instruments can lead to further complexities through the use of strategies aimed at assuring tax minimization: one way to trying to ensure that SPVs themselves - which are just intermediating receipts - are not subject to additional layer of tax, for example, is by locating them in low-tax jurisdictions. 


\section{TAX BENEFITS FOR CORPORATE DEBT FINANCING}

Tax is one of many determinants of corporate financial policies. Although the theory expects the existence of complete markets, perfect information, and no taxation, the reality is otherwise. Informational imperfections introduce considerations that can lead to a determinate choice and parceling of returns between equity and debt has real consequence. As [2] mentions, one longstanding issue is that there is an overall bias in many countries' tax systems which work to encourage corporate leverage. Changes in investment patterns and cross-border financial flows brought about by the twin forces of globalization and financial innovation may have significantly increased the impact of this bias in recent years. A systemic bias in favor of corporates financing themselves with debt (as opposed to equity) results from treating interest as a business cost in arriving at corporate profits, and so deductible for tax purposes against annual corporate profits, while treating returns to equity finance as a distribution of corporate profits, and not deductible in computing those. As a result profits may be taxed both at corporate and personal level when they are distributed as dividends.

According to [14], the greatest tax distortions in favor of debt financing will be in situations where there is no compensating increase in taxation at the level of the investor, compared with the taxation of dividends or capital gains on shares. Such a compensating increase could in theory arise if tax systems systematically compensated for the bias to corporate debt through reduced taxation of dividends and capital gains on shares. In practice, the distortion is greatest when the investor is tax exempt, or when tax is evaded, or when hybrid structures are used to achieve either a double deduction ("double dip") for the interest expense or relief for the interest expense with no corresponding taxation. Double-dip financing is a tax-planning strategy in certain cases involving the use of conventional debt, depending on the effective tax rate on interest income in the home country, compared with the effective tax rate on profit in the host country.

From a financial stability point of view, the key problem with high levels of leverage is that this makes companies more vulnerable to economic shocks and increases the probability of bankruptcy. Specifically, highly leveraged companies are particularly susceptible to volatility in profits (since they will be required to make interest payments irrespective of profitability) and-unless they have hedged-to volatility in currency or interest rates. If leverage levels become unsustainable and lead to a credit crunch, firms and households are left without access to the credit they need, leading to a collapse in demand. As [7] concludes, this tax distortion has gained more attention recently as the crisis has highlighted the fact that many companies have too high leverage ratios. This could lead to liquidity constraints, especially in times when banks tend to restrict their credit supply.

Not only [1] show that current corporate tax system in Europe favor debt financing over equity financing. While, in general, interest payments on corporate debt are deductible from the corporate tax base, return on equity is not. This leads to a higher leverage for firms since financing investments through debt is tax-favored. This tax distortion has gained more attention recently as the crisis has highlighted the fact that many companies have too high leverage ratios. This could lead to liquidity constraints, especially in times when banks tend to restrict their credit supply.

A well-designed tax base that reduces the distortion of the leverage could make companies less vulnerable to a short-term reduction in credits available on the capital market. There is indeed empirical evidence that the leverage of companies is indeed influenced by taxes. Several studies have analyzed this issue and find that debt policy is consistent with tax considerations (e.g. [15] or [16]). For instance, [16] have found that for stand-alone companies, an increase in the effective tax rate by one percentage-point increases the ratio of debt to assets by $0.18 \%$. The impact is larger for multinationals as it reaches $0.24 \%$ for two equal-size companies (with one foreign subsidiary) within the same group.

In principle, two opposing measures exist that might eliminate this distortion by treating both sources of finance in the same way: an allowance for corporate equity (ACE) or a comprehensive business income tax (CBIT). The ACE would grant a similar deduction for return on equity than for interest paid. This would abolish the tax advantage of debt. At the same time, ACE reduces the tax burden on marginal investment. ACE would also lead to a narrower tax base. In order to collect the same amount of tax revenue either the statutory corporate tax rate or other taxes have to be increased to finance such a reform. The CBIT, on the contrary, broadens the tax base by disallowing a deduction for interest payments on debt. If the tax rate remains unchanged, this leads to an increase in tax revenue. The additional revenue can be either used for a reduction in the statutory corporate tax rate or of other taxes if the reform is supposed to be revenue neutral. The tax neutrality of the financing decision is the same as in the ACE case since equity and debt financing are equally treated. ACE and CBIT have been discussed extensively in the economic literature as evidenced by [17]. Both systems are appealing due to their efficiency properties with regard to the financing decision of companies; however, there is no clear recommendation on which system is most favorable and there are key trade-offs when designing a reform towards any of these pure systems. While in the context of open economies ACE is more prone to profit shifting (in particular when its narrow tax base is accompanied by higher corporate tax rates), CBIT might lead to increased distortions of the marginal investment.

Recently, [18] has pointed on evidence of the tax bias to debt encouraging higher levels of gearing by companies, and banks have tended not only to gear up to the levels of debt allowed under regulatory capital rules but also to issue hybrid, equity-like, forms of debt, rather than ordinary share capital, where that satisfied both the regulators and the conditions for a tax deduction.

We can find an unclear premise concerning the tax incentive to debt financing. Generally, it presumes that, in order to obtain the credit and thus tax advantages of interest deductibility, corporations must change the risk profile of their obligations to the providers of capital. This may not be true, though, if a corporation can obtain the tax advantages 
without altering the character of its obligations. In principle this could be done by issuing hybrid instruments such as convertible debt obligations. Moreover, [19] notes that corporations often favor hybrid financing that qualifies as debt for tax but not for accounting purposes, thereby generating deductions against taxable income but not against financial statement earnings.

\section{THE TAXATION OF FINANCIAL INSTITUTIONS}

Although James Tobin first conceived the Financial Transaction Tax over 40 years ago, wider discussions about a possible taxation of the financial institutions have appeared after the financial crisis in 2008. According to [13], financial institutions face qualitatively the same tax considerations in balancing equity and debt finance as non-financial corporations. Banks have traditionally been able to sustain very high debt ratios by virtue of having relatively safe assets, and implicit or explicit deposit guarantees reinforce this. Besides, the high profitability of financial institutions in recent years will have made debt more attractive for them than for many non-financials, since the low probability of tax exhaustion it implies means a high effective corporate income tax rate. The study of [7] has presented the tax bias to debt runs counter to regulatory objectives. Banks face both an explicit tax advantage of debt and, through regulatory requirements, an implicit penalty-with evident risk of policy incoherence. Tax incentives towards high leverage may have undercut the effectiveness of regulatory requirements. The tension between regulatory objectives is reflected in the emergence of already mentioned hybrid financial instruments, which are treated like debt obligations for tax purposes (i.e., interest payments are deductible), but they are treated as capital rather than liabilities under banking regulations.

For example, [20] have analyzed the effectiveness of different government policies to prevent the emergence of banking crises. They have studied the impact on welfare of using tax-payers money to recapitalize banks, government injection of money into the banking system through credit lines, the creation of a buffer and taxes on financial transactions (the Tobin tax). Whilst the Tobin tax is an emergency policy (applied when a banking crisis is imminent), the creation of a buffer is a preventive one.

Next, [21] have stressed the negative externalities of large, complex financial institutions and recommended that policy makers quantify their systemic risk and tax their contributions to this risk. Systemic risk can be broadly thought of as the failure of a significant part of the financial sector - one large institution or many smaller ones - leading to a reduction in credit availability that has the potential to adversely affect the real economy. As stated by [3] the tax should be implemented through capital requirements or deposit insurance fees, rather than by trying to apply a tax directly to a base associated with the negative externality.

European Commission also has focused its attention on a possible taxation of the financial sector and has concluded that EU should introduce a system of levies or taxes on financial institution. On September 28, 2011, the European Commission formally proposed a plan to implement an
EU-wide financial transactions tax [22]. In October 2012, after discussions failed to establish unanimous support for an EU-wide financial transactions tax (FTT), the European Commission proposed that the use of enhanced cooperation should be permitted to implement the tax in the states which wished to participate. The proposal was supported by $11 \mathrm{EU}$ member states representing more than $90 \%$ of Eurozone GDP. The European Parliament resoundingly approved the plan in December 2012. On February 14, 2013 the European Commission adopted a proposal for an 11-nation financial transactions tax and it will come into force after being approved by the participating member states and the European Parliament. The target starting date is January 1, 2014 [23].

The tax would be levied on all transactions on financial instruments between financial institutions when at least one party to the transaction is located in the EU. It would cover $85 \%$ of the transactions between financial institutions, but not affect citizens and businesses. The European Commission itself expects the FTT to have the following impact on financial markets and the real economy:

- Up to a 90 per cent reduction in derivatives transactions;

- Negative or positive effect on economic growth;

- An effective curb on automated high-frequency trading and highly leveraged derivatives;

- An increase in capital costs, which could be mitigated by excluding primary markets for bonds and shares from the tax

- The real economy could be protected by ensuring the tax is levied only on secondary financial products, thus not affecting transactions such as salary payments, corporate and household loans [24].

However, there is not unambiguous consent that FTT on its own would prevent financial crises. We clearly agree with [25] that FTT would somewhat reduce systemic risk, but prudent macroeconomic policies and effective financial regulation as well as supervision have a major role in crisis prevention. However, by significantly reducing the level of noise trading in general and reducing (or eliminating) high frequency trading in particular, the FTT would make some contribution to the reduction of severe misalignments and hence the probability of violent adjustments. Moreover, in financial crises "gross" exposures matter more than the net ones, and financial transaction taxes will reduce the gap between them.

\section{CONCLUSION}

The aim of the paper was to review the main channels through which the tax policy can contribute to the crisis. We can conclude that the most important elements of the tax system affecting financial crisis are: the tax benefits for corporate debt financing, the taxation of financial institutions, tax competition, tax reliefs for housing and capital gains, the incoherence of capital income taxation like tax arbitrage, tax clienteles and derivative securities, the use of tax havens for creating tax efficient securitization instruments and the tax prioritization of the performance-based remuneration.

There is evidence that the tax system played a major role in triggering the tax crisis. On the other side, a number of 
special taxes have been introduced and proposed to recover the cost of the -bailout. The debate has highlighted that taxation may be used as corrective instrument to complement prudential regulation of the banking sector. Financial transaction tax has been adopted as a tool to stabilize financial markets and improve their functioning because a large number of transactions are either speculative or of no social use.

It should be stressed that many of the defining elements of the pre-crisis financial sector were global in scope. The main root causes of the crisis, e.g. cross-border debt balances, exploitation of differences in regulation and in market prices and the market for the highest-yielding investments, were also global. In spite of that, there is a tension between global integration of markets and nationally based regulation. But in a globally competitive market, market players will seek the most advantageous regulatory environment for financial transactions and exploit differences in national regulations, so the regulatory activities must also be global.

\section{REFERENCES}

[1] T. Hemmelgarn and G. Nicodeme. (January 2010). The 2008 Financial Crisis and Taxation Policy. CESifo Working Paper Series No. 2932. [Online]. Available: http://ssrn.com/abstract=1546973

[2] G. Lloyd. (April 2009). Moving beyond the Crisis: Tax Policies for the Soundness of Financial Markets. [Online]. Available: http://www.itdweb.org/documents/Geoff_Lloyd_Newsletter_Special_ July_09OECD_tax_and_financial_markets.pdf

[3] J. Slemrod, "Lessons for tax policy in the great recession," presented at the National Tax Association Spring Meeting, Washington, DC, May 21, 2009.

[4] M. Keen, A. Klemm, and V. Perry, "Tax and the crisis," Fiscal Studies, vol. 31, pp. 43-79, March 2010.

[5] M. Giuli, "Learning from the financial crisis: tax competition and income inequalities," Madariaga Paper, vol. 3, pp. 1-19, January 2010.

[6] V. Ceriani, S. Manestra, G. Riccoti, A. Sanelli, and E. Zangari, "The tax system and the financial crisis," Questioni di Economia e Finanza (Occasional papers), vol. 85, pp. 1-39, January 2011.

[7] International Monetary Fund. (July 2009). Debt Bias and Other Distortions: Crisis-Related Issues in Tax Policy. CESIFO Working Paper 2932. No. [Online]. Available: http://www.imf.org/external/np/pp/eng/2009/061209.pdf

[8] P. V. D. Noord and C. Heady. (July 2001). Surveillance of Tax Policies: A Synthesis of Findings in Economic Surveys. OECD Economics Department Working Papers, No. 303. [Online]. Available: http://dx.doi.org/10.1787/034063184564

[9] P. V. D. Noord, "Tax incentives and house price volatility in the Euro area: theory and evidence," Économie international, vol. 101, pp. 29-45, 2005.

[10] A. Johansson, C. Heady, J. Arnold, B. Brys, and L. Vartia. (July 2008). Tax and economic growth. OECD Working Paper No.28/08. [Online] Available: http://www.olis.oecd.org/olis/2008doc.nsf/linkto/eco-wkp(2008)28.

[11] A. Hilbers, A. W. Hoffmaister, A. Banerji, and A. Shi. (October 2008). House price developments in Europe: a comparison. IMF Working Paper, No. 08/211. [Online]. Available: http://www.imf.org/external/pubs/ft/wp/2008/wp08211.pdf

[12] B. Lutz, R. Molloy, and H. Shan, "The housing crisis and state and local government tax revenue: Five channels," Regional Science and Urban Economics, vol. 41, pp. 306-319, July 2011.

[13] S. T. Eddins. (March 2009). Tax Arbitrage Feedback Theory. [Online]. Available:

http://papers.ssrn.com/sol3/papers.cfm?abstract_id=1356159
[14] J. Alworth and G. Arachi, Taxation and the Financial Crisis, 1st ed. Oxford, U.K.: Oxford University Press, 2012.

[15] M. A. Desai, F. C. Foley, and J. R. Hines Jr., "A multinational perspective on capital structure choice and internal capital markets," Journal of Finance, vol. 59, pp. 2451-2487, December 2004.

[16] H. Huizinga, L. Laeven, and G. Nicodeme, "Capital structure and international debt shifting," Journal of Financial Economics, vol. 88, pp. 80-118, April 2008.

[17] M. P. Devereux and R. A. de Mooij, "Alternative systems of business tax in Europe: An applied analysis of ACE and CBIT Reforms," Taxation Papers, vol. 17, pp. 1-155, May 2009.

[18] H. Lierse, "European taxation during the crisis: does politics matter?" Journal of Public Policy, vol. 32, pp. 207-230, December 2012.

[19] D. Shaviro. (January 2011). The 2008 Financial Crisis: Implications for Income Tax Reform. NYU Law and Economics Research Paper No. 09-35. [Online]. Available: http://dx.doi.org/10.2139/ssrn.1442089

[20] A. Hasman, A. L. Lopez, and M. Samartin, "Government, taxes and banking crises," Journal of Banking \& Finance, vol. 35, pp. 2761-2770, October 2011.

[21] V. V. Acharya and M. Richardson, Restoring Financial Stability: How to Repair a Failed System, 1st ed., New Jersey, USA: John Wiley, 2009.

[22] European Commission (2011), COM (2011) 594.

[23] European Commission, "Proposal for a council directive implementing enhanced cooperation in the area of financial transaction tax," Brussels, 14 Feb. 2013.

[24] A. Hagelüken. (2012). Und sie funktioniert doch. [Online]. Available: http://www.sueddeutsche.de/wirtschaft/eu-studie-zur-finanztransaktio nssteuer-und-sie-funktioniert-doch-1.1353438

[25] S. Griffith-Jones and A. Persaud A. (2012). Financial Transactions Taxes. [Online]. Available: http://www.europarl.europa.eu/document/activities/cont/201202/2012 0208ATT37596/20120208ATT37596EN.pdf

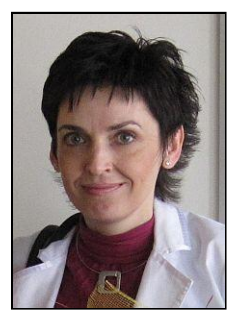

Irena Szarowská was born in Bojnice (Slovak Republic) on June 21, 1972. She graduated at School of Business Administration in Karvina, Silesian University (SBA SU, Czech Republic) in 1995 master study (Finance and Banking). In May 2011, she completed the doctoral research and defended her thesis - the study program in Economics and Management at the SBA SU (Ph.D. degree). She has worked in a leasing company and after that in a mortgage bank as a business manager. In the Department of Finance at the School of Business Administration of the Silesian University in Karvina, she has been employed as a full-time Assistant Professor since March 2005. Since September of 2008 she has been the Deputy Head of the Department of Finance. She lectures the courses Public Finances, and Money, banking and Financial Markets. She teaches regularly issues of public finances at foreign universities (North Karelia University of Applied Sciences, Joensuu, Finland; Instituto Politécnico de Braganca, Braganca, Portugal; BA School of Business and Finance, Riga, Latvia). She has published several research papers and appeared in international journals and ISI conference proceedings (e.g. Tax harmonization and the effects of tax changes on economic growth. In MATOUŠEK, R., STAVÁREK, D. Financial integration in the European Union. Abingdon, Oxon: Routledge, 2012, pp. 234-255; Public Spending Cyclicality and Wagner's Law in Central and Eastern European Countries. Acta Univ. Agric. et Silvic. Mendel. Brun., 2012, vol.60 (2), pp. 383-390; The effect of tax burden on economic growth in the European Union. In Proceedings of the 28th International Conference on Mathematical Methods in Economics 2010. České Budějovice: University of South Bohemia, 2010, pp. 596-601). Her research interests are related to public finances, tax burden, tax competition and harmonization. Dr. Szarowská is a member of Czech Economic Society and a member of international editorial board of scientific journals Public Administration \& Regional Studies, and Acta Universitatis Danubius Economica. 